\title{
CORPORATE ENTREPRENEURSHIP - DISTILLING THE CONCEPT
}

\author{
Colene Hind * \\ hindc@unisa.ac.za
}

\author{
Renier Steyn \\ steynr@unisa.ac.za \\ UNISA Graduate School of Business Leadership \\ *To whom correspondence should be addressed
}

\section{ABSTRACT}

Background: Corporate entrepreneurship (CE) is credited for many positive organisational outcomes, including systemic growth and increased revenue. Several terms associated with CE, including strategic renewal, corporate venturing and intrapreneurship are frequently used interchangeably and often confuse scholars, researchers and practitioners. The lack of clarity about the exact meaning of these terms is detrimental to the synergy in the current body of knowledge and the development of models involving these concepts. Objective: The aim of this paper was to describe CE as a unique concept, distinguishable from related concepts. Methodology: Several definitions of CE as well as the related terms were dissected, to identify core elements associated with each of them. The validity of these comprehensive definitions was tested by requesting 68 master's degree students to classify the definitions. Inter-rater reliabilities were calculated in order to assess the level of agreement in the classification of the constructs. Results: The results indicate that $\mathrm{CE}$ is difficult to distinguish from strategic renewal and corporate venturing, but that intrapreneurship seems to be better defined and separate from the other constructs. Conclusion: These results emphasise the conceptual confusion that exists around CE and the need for further clarification of terminology.

\section{KEY WORDS}

Corporate entrepreneurship, strategic renewal, corporate venturing, intrapreneurship. 


\section{INTRODUCTION}

Increasingly research is confirming the importance of establishing corporate entrepreneurship (CE) as an essential success strategy (Hornsby, Kuratko, Holt \& Wales, 2013:937), and has a direct positive influence on organisational performance (Bojica \& del Mar Fuentes Fuentes, 2012: 397 \& Urbano \& Turro, 2013: 379). Engaging in CE is credited for many positive organisational outcomes, including increased shareholder value, creating and sustaining corporate competitiveness and innovation. With regard to shareholder value Zahra, Neck and Kelly (2004: 145) find that CE skills development has become essential if organisations are to create value for their shareholders by competing in new markets. Zahra (1996: 1713) makes a similar link, with reference to the value for shareholders. The author finds a positive association between executive ownership of company stock and CE, as well as long-term institutional ownership by using data from 127 Fortune 500 companies. CE can be seen as a valuable wealth creation process (Ireland, Hitt, Camp \& Sexton, 2001: 49). A literature review by Antonic and Hisrich (2004: 518) makes it is clear that CE is imperative to corporate vitality and wealth generation in the present world economy.

With reference to creating and sustaining corporate competitiveness, Barringer and Bluedorn (1999: 421) point out that CE is a significant contributor to the rejuvenation of organisations, and in cases their survival. Covin and Miles (1999: 47) and Goodale, Kuratko, Hornsby and Covin (2011: 116) add that CE can be utilised to improve an organisations' competitive positioning through transformation of industries, products and markets or exploiting value-creating innovation. Teng (2007: 119) states that for a firm to successfully and consistently be faster than its competitors, collective CE activity is essential. Covin and Miles (1999: 47) further suggest that certain generic forms of CE can be successfully utilised as methods towards competitive advantage.

As for innovation, given the challenges in developing future competencies balanced with nurturing present competencies, modern-day firms increasingly rely on CE as a means of coping (Kuratko, Ireland \& Hornsby, 2004: 7). Roffe 
(1999: 227) finds innovation to be a crucial element in the wellbeing of organisations. The practice of CE enhances an organisation's ability to practise this crucial element of innovation. Zahra (1991: 259) and Coad and Rao (2008: 633) use the term "super-star" growth when observing growth in high-tech sectors, and state that this type of growth is inseparable form innovation.

Many more positive outcomes are associated with CE. These include job creation (Christensen, 2005: 305), successful international venturing (Yiu, Lau \& Burton, 2007: 519; Zahra \& Garvis, 2000: 469), stimulating while at the same time capitalising on creative thinkers (Hisrich, Peters \& Shepherd, 2010: 36) and a positive association with financial and overall organisational performance (Zahra, 1991: 259; Zahra, 1995: 43).

Zahra (2005: xv), in the introduction of a special journal edition on corporate entrepreneurship expresses frustration at the absence of a "unified and widely excepted" definition of the concept of CE. Several terms associated with CE can be found in the academic literature, including strategic renewal, corporate venturing and intrapreneurship. However, the existence of a general, agreed on definition is difficult to find (van Wyk \& Andonisi, 2012: 66) and ambiguities in terminology used exist (Sharma \& Chrisman, 1999: 13). Barreira, Dhliwayo, Luiz, Naude and Urban (2012: 139) echoes this and suggest that authors do not distinguish between the terms "corporate entrepreneurship" and "intrapreneurship". Parker (2011: 19) demonstrates this ambiguity and notes that intrapreneurship is also known as corporate entrepreneurship or corporate venturing. Hornsby, Kuratko and Zahra (2002: 254; seminal authors in the field of CE) further illustrate these ambiguities when they state that CE is also referred to as corporate venturing or intrapreneurship. From the aforementioned, and stated by Covin and Miles (1999: 48), the term CE is sometimes used broadly, to refer to multiple concepts, and sometimes very specific, referring to well-defined concepts. Even though there are some agreement on what $\mathrm{CE}$ is, authors use different terms when expressing themselves on this topic (Sharma \& Chrisman, 1999: 11). 
Fifteen years ago, Sharma and Chrisman (1999: 11) notes that for researchers to be able to build on existing work it is imperative that the research concept be clearly defined. The authors extend this importance beyond the academic field to practitioners. Sharma and Chrisman (1999: 11) state that only when concepts are clearly defined can practitioners decide whether research findings are indeed applicable to them. This concern is still valid and Cooper and Schindler (2011: 54) stated that clarity regarding a concept also saves future time and money spent on research efforts.

\section{RESEARCH}

The aim of this research was to present definitions unique to $C E$ and the related terms of strategic renewal, corporate venturing and intrapreneurship. This aim was achieved with cognisance of similar research on differentiating between CE-related terms done by Nath (2007, no page) and Sharma and Chrisman (1999: 11).

\section{LITERATURE REVIEW}

Before exploring definitions of terms in the field of CE, let us briefly turn to its root term, namely entrepreneurship, and progress made in distilling the meaning of this concept. A significant amount of studies in the field of entrepreneurship exists, yet the debate regarding an agreed upon definition for this root construct is very much alive (Howorth, Tempest \& Coupland, 2005: 24). Davidsson (2003: 316) states that the literature is lavished with definitions, however all these definitions differ along several dimensions. These dimensions include dispositions, outcomes, behaviour and even to which domain the discipline belongs. Hansen, Shrader and Monllor (2001: 285) note the presence of not only ambiguities in definitions but even contradictions. It is clear that agreement on exactly what constitutes entrepreneurship is still lacking (Landstrom, Harirchi \& Astrom, 2012: 1154).

Despite the above-mentioned confusion, some authors agree on certain mutual elements in the definition of entrepreneurship. Nieman, Hough and Nieuwenhuizen (2003: 9), for example, summarise the key concepts derived from a number of definitions. These concepts are: the entrepreneurs' ability to 
identify an opportunity, the novelty of the opportunity (creativity and innovation), the entrepreneurs' ability to gather the necessary resources, and then creating and growing the venture, a propensity for risk-taking, management ability and finally some kind of reward as a result of the entrepreneurs' efforts. The fact that there is growing consensus regarding the meaning of what entrepreneurship entails brings forth hope that, with time and discussion, concepts such as CE will be used with more precision. However, it must be acknowledged that small differences would continue to exist, based on the specific disciplinary lens applied in each study on CE.

Strategic renewal, corporate venturing and intrapreneurship seem to be the terms most used in the literature when referring to corporate entrepreneurship. Definitions of the concepts associated with CE are presented below to obtain a comprehensive understanding of these concepts as presented in literature. The presented list of verbatim definitions was limited to four due to space constraints. However, references are made to other authors who have defined the concepts, and whose definitions were read. Following the presentation of the definitions found in the literature, a comprehensive and distinct definition of each of the concepts was developed. These definitions were formulated with due consideration of the core elements of those provided and cognisance of the definitions of the related terms. This process will be explained further in the methodology section.

\section{Corporate entrepreneurship (CE)}

The following are definitions of CE. These definitions were selected from a long list of definitions based on recency as well as comprehensiveness.

$\ldots$ is seen as the sum of a company's innovation, renewal, and venturing efforts (CE1; Zahra,1995: 227).

$\ldots$ is generally believed to refer to the development of new ideas and opportunities within large or established businesses, directly leading to the improvement of organizational profitability and an enhancement of 
competitive position or the strategic renewal of an existing business (CE2; May, 2014: no page).

... the term used to describe entrepreneurial behavior in an established, larger organization. ... to gain a competitive advantage by encouraging innovation at all levels in the organization (CE3; Burns, 2008: 13).

... the process by which teams within an established company conceive, foster, launch and manage a new business that is distinct from the parent company but leverages the parent's assets, market position, capabilities or other resources. It differs from corporate venture capital, which predominantly pursues financial investments in external companies (CE4; Wolcott \& Lippitz, 2007: 75).

Barreira, Dhliwayo, Luiz, Naude and Urban (2012: 139), Barringer and Bluehorn (1999: 139), Birkinshaw (1997: 208), Corbett, Covin, O'Connor and Tucci (2013: 812), Covin and Miles (1999: 49), Gomez-Haro, Aragon-Correa and Cordon-Pozo (2001: 1678), Guth and Ginsburg (1990: 5), Hornsby, Kuratko and Zahra (2002: 254), Kuratko, Morris and Covin (2011: 110), Morris, Kuratko and Covin (2008: 11), Sharma and Chrisman (1999: 18), Zahra (1995: 260-261), Zahra (1996: 1714-1715) and Zahra and Covin (1995: 44) also provide definitions of CE. The aforementioned list of definitions, as well as the verbatim definitions, and definitions of the related terms, were considered when formulating a unique CE definition. CE was defined as "a broad concept which refers to strategic organizational adaptation to improve an organization's position".

\section{Strategic renewal}

Strategic renewal can be defined as follows:

(The) phenomenon whereby the organization seeks to redefine its relationship with its markets or industry competitors by fundamentally altering how it competes (SR1; Covin \& Miles, 1999: 52). 
An evolutionary process associated with promoting, accommodating, and utilizing new knowledge and innovative behaviour in order to bring about change in an organization's core competencies and/or change in its product market domain (SR2; Hopkins, Malette \& Hopkins, 2013: 77).

... involves the creation of new wealth through new combinations of resources (SR3; Guth \& Ginsberg, 1990: 6).

... corresponds to a broader array of entrepreneurial initiatives that do not necessarily involve new businesses being added to the firm. All forms of this phenomenon have one thing in common: They all involve organizationally consequential innovations that are adopted in the pursuit of competitive advantage (SR4; Kuratko et al, 2011: 97).

Corbett, Covin, O'Connor and Tucci (2013: 812), Dess, Ireland, Zahra, Floyd, Janney and Lane (2003: 335), Sáez-Martínez and González-Moreno (2011: 44), Agarwal and Helfat (2009: 282), and Flier, Van den Bosch and Volberda (2003: 2168) also provide definitions of strategic renewal and their definitions, with the definition of the related constructs, were considered when defining the construct. Strategic renewal was defined as "primarily internal changes to the organisation which occurs as a result of strategic organisational adaptation".

\section{Corporate venturing}

The following definitions of corporate venturing are typical of those used in literature and are quoted as examples:

... the process of actively investing in small start-up business by large firms (CV1; Birkinshaw, Van Batenburg \& Murray, 2002: 11). 
It involves investment in high-risk activities that generate new business within or closely related to the activities of the parent corporation (CV2; Husted \& Vintergaard, 2004: 296).

...concerned with larger businesses needing to manage new, entrepreneurial business separate from the mainstream activity (CV3; Burns, 2008: 13)

(It) involves entrepreneurial efforts in which established business organizations invest in and/or create new businesses (CV4; Sharma \& Chrisman, 1999: 18).

Basu and Wadhwa (2013: 965), Birkinshaw (1997: 208), Guth and Ginsberg (1990: 6), Kuratko, Montagno and Hornsby (1990: 50), Miles and Covin (2002: 21), Kuratko et al (2011: 86) and Thornhill and Amit (2000: 26) also provide definitions of the concept. Given these and the other definitions provided in this section, corporate venturing was defined as to refer to "the creation or acquisition of new business units with the aim to improve the organisation's position".

\section{Intrapreneurship}

The following are definitions of intrapreneurship:

... individual or individuals (who) champion new product ideas within a corporate context (11; Covin \& Miles, 1999: 48).

The act of behaving like an entrepreneur while working within a large organization (I2; Murray, 2012).

Individuals who are typically defined as intra-organizational revolutionaries entrepreneurs within established organizations (I3; Teltumbde, 2006: 129). 
...a peculiar mix of skills that combine attributes of the entrepreneur with those of corporate managers (14: Sayeed \& Gazdar, 2003:76).

Definitions of the concept are also provided by Burns (2008: 13), Kuratko, Montagno and Hornsby (1990:49), Moriano, Molero, Topa \& Levy Mangin (2014: 103) Villiers-Scheepers (2011: 250) and Subramanium (2005: 488). Given the aforementioned literature, intrapreneurship was defined as to refer to "the employee activities which facilitates entrepreneurial activity within an organization".

\section{METHODOLOGY}

An exploratory study was conducted. This is necessary with $\mathrm{CE}$, because there is a lack of clarity relating to the concept and this justifies such exploration (Cooper \& Schindler, 2011: 143). The first objective was to develop simple yet comprehensive definitions of CE and the related terms.

The unit of analysis was direct or verbatim quotes of definitions of the concepts under discussion, namely $\mathrm{CE}$, corporate venturing and entrepreneurship. These concepts were selected because of their prominence in the CE literature and specifically the reference of Hornsby et al. (2002; a seminal work in the area of CE), who states that these concepts are used interchangeably. The definitions were primarily from journal articles, but some academic textbooks were also used. In total 43 definitions were collected.

The definitions were listed by the authors in table form to ease the analysis process. Similarities and differences were identified and summarised. This was done on a concept level and across concepts. Based on this analysis comprehensive definitions were developed by the authors. The aim was capturing the essence of each of the concepts. In table 1 the results of this process are reported.

To determine if these new definitions of the concepts effectively capture the essence of the constructs and allow readers to effectively differentiate between the constructs, the assistance of master's degree students were 
requested. Those willing to participate were asked to classify the source definitions (those used to develop the new definitions) according to the new, comprehensive definitions. The verbatim source definitions were provided to the students with the reference of the concept being defined left out. Table 2 resembles the design of the form on which the respondents indicated their answers.

Next, a statistical test was sourced to determine to what extent the respondents were able to classify the source definitions to correspond with those definitions developed by the authors. Inter-rater reliability, as described by Shaughnessy, Zechmeister and Zechmeister (2009: 122) was used. They state that inter-rater reliability is simply the number of times observers agreed divided by the times they had the opportunity to agree, presented as a percentage. They also state that "although there is no hard-and-fast percentage of agreement that defines low inter-rater reliability, researchers generally report estimates of reliability that exceed 85\%" (Shaughnessy at al, 2009: 122). This margin was set as the margin of acceptance in this research. Should this level be achieved, it will be indicative of the success of the comprehensive definition in capturing the essence of the construct.

\section{FINDINGS}

The first group of findings are the comprehensive definitions developed from literature. These are presented in table 1. 
Table 1

Comprehensive definitions of $\mathrm{CE}$, strategic renewal, corporate venturing and intrapreneurship

\begin{tabular}{|l|l|}
\hline Concept & Definitions \\
\hline CE & $\begin{array}{l}\text { CE is a broad concept which refers to strategic } \\
\text { organizational adaptation to improve an organization's } \\
\text { position. }\end{array}$ \\
\hline Strategic renewal & $\begin{array}{l}\text { Strategic renewal is primarily internal changes to the } \\
\text { organisation which occurs as a result of strategic } \\
\text { organisational adaptation. }\end{array}$ \\
\hline Corporate & $\begin{array}{l}\text { Corporate venturing is the creation or acquisition of new } \\
\text { business units with the aim to improve the } \\
\text { organisation's position. }\end{array}$ \\
\hline Intrapreneurship & $\begin{array}{l}\text { Intrapreneurship is the employee activities which } \\
\text { facilitates entrepreneurial activity within an organisation. }\end{array}$ \\
\hline
\end{tabular}

The respondents were asked to classify source definitions under the headings of the definitions provided in table 1 . Table 2 presents data on the consensus about the representivity of these definitions. The matches are presented in bold. 
Table 2

Respondent's classification of source definitions

\begin{tabular}{|c|c|c|c|c|c|}
\hline \multirow{2}{*}{\multicolumn{2}{|c|}{\begin{tabular}{|l|} 
Source \\
definitions
\end{tabular}}} & \multicolumn{4}{|c|}{ Comprehensive definitions } \\
\hline & & \multirow{2}{*}{$\begin{array}{l}\text { CE } \\
33\end{array}$} & \multirow{2}{*}{\begin{tabular}{|l} 
SR \\
$\mathbf{2 8 ^ { a } / 6 8 ^ { b }}$ \\
$=0.411^{c}$
\end{tabular}} & \multirow{2}{*}{$\begin{array}{l}\text { CV } \\
7\end{array}$} & \multirow{2}{*}{\begin{tabular}{|l}
1 \\
0
\end{tabular}} \\
\hline 1 & SR1 & & & & \\
\hline 2 & 11 & 4 & 3 & 13 & $48 / 68=0.705$ \\
\hline 3 & CV1 & 7 & 2 & $51 / 68=0.750$ & 8 \\
\hline 4 & CE1 & $28 / 68=0.411$ & 24 & 14 & 2 \\
\hline 5 & SR2 & 23 & $34 / 68=0.500$ & 5 & 6 \\
\hline 6 & CE2 & $26 / 68=0.382$ & 23 & 12 & 7 \\
\hline 7 & CV2 & 8 & 8 & $49 / 68=0.720$ & 3 \\
\hline 8 & 12 & 5 & 1 & 3 & $59 / 68=.867$ \\
\hline 9 & SR3 & 7 & $18 / 38=0.264$ & 39 & 4 \\
\hline 10 & 13 & 2 & 1 & 2 & $63 / 68=0.926$ \\
\hline 11 & CV3 & 14 & 13 & $38 / 68=0.558$ & 3 \\
\hline 12 & CV4 & 5 & 7 & $51 / 68=0.750$ & 5 \\
\hline 13 & CE3 & $25 / 68=0.367$ & 14 & 1 & 28 \\
\hline 14 & SR4 & 26 & $33 / 68=0.485$ & 7 & 2 \\
\hline 15 & 14 & 8 & 1 & 3 & $56 / 68=0.823$ \\
\hline 16 & CE4 & $16 / 68=0.235$ & 22 & 23 & 7 \\
\hline \multicolumn{2}{|c|}{$\begin{array}{l}\text { Average } \\
\text { reliability }\end{array}$} & 0.349 & 0.415 & 0.694 & 0.830 \\
\hline
\end{tabular}

${ }^{\mathrm{a}}$ The number of individuals who could pair the source definition with the new definition.

${ }^{b}$ This is $n=$ the number of individuals who could have paired the definitions correctly.

${ }^{\mathrm{C}}$ The inter-rater reliability .

From table 2 it can be observed that the average reliability for $\mathrm{CE}$, strategic renewal and corporate venturing was far below the margin set by Shaughnessy et al (2009: 122). Although close to the margin of .85, the value of intrapreneurship was below this level. In no cases did the respondents agree, to the satisfaction of the set guideline, with the creators of the 
comprehensive definition, that the source definitions feed into the comprehensive definitions.

\section{DISCUSSION}

The authors of this paper went to great lengths to create a simple yet comprehensive definition of $\mathrm{CE}$ and the related terms. The authors were convinced, as many before them, that their definitions captured the essence of the source information they used. They were also convinced that the definitions were developed in such a way as to be unambiguous, leaving no doubt as to what is defined. Testing the validity of this conviction, the authors engaged 68 master's degree students, to assess to what extent they concur. The expectations of the authors were not met, and in none of the cases did the respondents concur sufficiently with the authors on the way they applied the source definitions.

\section{RECOMMENDATIONS}

The authors failed to provide definitions that were seen as representative of $\mathrm{CE}$ and the related terms. Respondents were still confused about how the final definitions related to their presumed sources. A way to address the problem of not being able to distinguish between terms may be addressed by shying away from the use of the terms (say CE, entrepreneurship, intrapreneurship) and rather using descriptions when dealing with these matters. It may be more useful to say "I am investigating a broad concept which refers to strategic organizational adaptation to improve an organization's position" than "I am investigating CE".

\section{LIMITATIONS OF THE STUDY}

The use of students as respondents is also limiting, firstly as they had very little to gain from participating in the study and as such legitimate questions may be asked about their motivation to engage in the material. The motivation of the participant could be enhanced by offering incentives to participate or linking their participation to their own learning or projects in which they are involved. Secondly participants were students enrolled in a master's course that covers material on general business aspects. The course material does 
not cover specific information on entrepreneurship or corporate entrepreneurship. Thus, their lack of background knowledge in the field could be seen as a limitation.

\section{CONCLUSION}

The last word on how to define $\mathrm{CE}$, and the related terms, has not been written yet. As is the case with entrepreneurship, the road to finding some clarity on how to define CE may be a long road. The authors take comfort in the fact that use of a term such as entrepreneurship still confuses academics and practitioners alike.

"Examine your words well, and you will find that even when you have no motive to be false, it is a very hard thing to say the exact truth."

- George Eliot, Adam Bede -

\section{REFERENCES}

Agarwal, R \& Helfat, CE. 2009. Strategic renewal of organisations. Organisation Science, 20(2):281-293.

Barreira, J, Dhliwayo, S, Luiz, J, Naude, W \& Urban, B. 2012. Frontiers in Entrepreneurship. (5th ed). Johannesburg: Heinemann Publishers.

Barringer, BR \& Bluedorn, AC. 1999. The relationship between corporate entrepreneurship and strategic management. Strategic Management Journal, 20: 421-444.

Basu, S \& Wadhwa, A. 2013. External venturing and discontinuous strategic renewal: An options perspective. Journal of Product Innovation Management, 30(5): 956-975.

Birkinshaw, J. 1997. Entrepreneurship in multinational corporations: the characteristics of subsidiary initiatives. Strategic Management Journal, 18(3): 207-229.

Birkinshaw, J, Van Batenburg, R \& Murray, G. 2002. Venturing to succeed. Business Strategy Review, 13(4): 10-17. 
Bojica, AM \& Del Mar Fuentes Fuentes, M. 2012. Knowledge acquisition and corporate entrepreneurship: Insights from Spanish SMEs in the ICT sector. Journal of World Business, 47(3): 397-408.

Burns, P. 2008. Corporate entrepreneurship. Building the entrepreneurial organization. (2nd ed) London. Palgrave Macmillan.

Christensen, KS. 2005. Enabling intrapreneurship: the case of a knowledgeintensive industrial company. European Journal of Innovation Management, 8(3): 305-322.

Coad, A \& Rao, R. 2008. Innovation and firm growth in high-tech sectors: A quantile regression approach. Research Policy, 37: 633-648.

Cooper, RC \& Schindler, SS. 2011. Business research methods. London: McGraw-Hill Education.

Corbett, A, Covin, JG, O'Connor, GC \& Tucci, CL. 2013. Corporate entrepreneurship: State-of-the-art research and a future agenda. Journal Of Product Innovation Management, 30(5): 812-820.

Covin, JG \& Miles MP. 1999. Corporate entrepreneurship and the pursuit of competitive advantage. Entrepreneurship Theory \& Practice, Spring: 47-63.

Davidsson, P. 2003. The domain of entrepreneurship research: some suggestions. Advances in Entrepreneurship, Firm Emergence and Growth, 6: 315-372.

Dess, GG, Ireland, RD, Zahra, SA, Floyd, SW, Janney, JJ \& Lane, PJ. 2003. Emerging issues in corporate entrepreneurship. Journal of Management, 29(3): 351-378.

Flier, B, Van den Bosch, FAJ \& Volberda, HW. 2003. Co-evolution in strategic behaviour of British, Dutch and French financial incumbents: Interaction of environmental selection, institutional effects and managerial intentionality. Journal of Management Studies, 40(8): 2163-2187.

Gomez-Haro, S, Aragon-Correa, JA \& Cordon-Pozo, E. 2011. Differentiating the effects of the institutional environment on corporate entrepreneurship. Management Decision, 49(10): 1677-1693.

Goodale, CJ, Kuratko, DF, Hornsby, JS, Covin, JG. 2011. Operations management and corporate entrepreneurship: The moderating effect of operations control on the antecedents of corporate entrepreneurial activity in 
relation to innovation performance. Journal of Operations Management, 29: $116-127$.

Guth, WD \& Ginsberg, A. 1990. Guest editors' introduction: corporate entrepreneurship. Strategic Management Journal, 11: 5-15.

Hansen, DJ, Shrader, R \& Monllor, J. 2001. Defragmenting definitions of entrepreneurial opportunity. Journal of Small Business management, 49(2): 283-304.

Hisrich, RD, Peters, MP \& Shepherd, DA. 2010. Entrepreneurship. (9th ed.). New York: McGraw-Hill.

Hopkins, WE, Malette, P \& Hopkins, SA. 2013. Proposed factors influencing strategic inertia/strategic renewal in organisations. Academy of Strategic Management Journal, 12(2): 77-94.

Hornsby, JS, Kuratko, DF, Holt, DT \& Wales, WJ. 2013 Assessing the measurement of organizational preparedness for corporate entrepreneurship. Journal of Product Innovation Management, 30(5): 937-955.

Hornsby, JS, Kuratko, DF and Zahra, SA. 2002. Middle managers' perception of the internal environment for corporate entrepreneurship: assessing a measurement scale. Journal of Business Venturing, 17: 253-273.

Howorth, C, Tempest, S \& Coupland, C. 2005. Rethinking entrepreneurship methodology and definitions of the entrepreneur. Journal of Small Business Enterprise Development, 12(1): 24-40.

Husted, K \& Vintergaard, C. 2004. Stimulating innovation through corporate venture bases. Journal of World Business, 39: 296-306.

Ireland, RD, Hitt, MA, Camp, M \& Sexton, L. 2001. Integrating entrepreneurship and strategic management actions to create firm wealth. Academy of Management Perspectives, 15(1): 49-63.

Kuratko, DF, Ireland, RD \& Hornsby, JS. 2004. Corporate entrepreneurship behaviour among managers: a review of theory, research and practice. Advances in Entrepreneurship, Firm emergence and Growth, 7: 7-45.

Kuratko, DF, Montagno, RV \& Hornsby, JS. 1990. Developing an intrapreneurial assessment instrument for an effective corporate entrepreneurial environment. Strategic Management Journal, 11: 49-58. 
Kuratko, DF, Morris, MH \& Covin, JG. 2011. Corporate Innovation and Entrepreneurship. (3rd ed). Canada. Cengage Learning.

Landstrom, H, Harirchi, G, \& Astrom, F. 2012. Entrepreneurship: Exploring the knowledge base. Research Policy, 41: 1154-1181.

May, R. 2014. Corporate entrepreneurship and its importance in large companies.

Retrieved

from:

http://www.businessdictionary.com/article/726/corporate-entrepreneurshipand-its-importance-in-large-companies/ Accessed: 04-02-2014.

Miles, MP \& Covin, JG. 2002. Exploring the practice of corporate venturing: some common forms and their organisational implications. Entrepreneurship Theory and Practice, Spring: 21-40.

Moriano, JA, Molera, F, Topa, G \& Levy Mangin, J-P. 2014. The influence of transformational leadership and organizational identification on intrapreneurship. International Entrepreneurship Management Journal, 10(2014): 103-119.

Morris, MM, Kuratko, DF \& Covin, JG. 2008. Corporate entrepreneurship and innovation. (2nd ed). Mason. Thomson Higher Education.

Murray, S. 2012. Get the boss to embrace your innovation. Retrieved from: http://www.ft.com/cms/s/0/ab16a1a6-87b8-11e1-ade2-

00144feab49a.htm|\#axzz2sLddCUZg Accessed: 04-02-2014.

Nath, CL. 2007. Corporate Entrepreneurship: A Strategic and Structural Perspective. Paper presented at the Seventh Biennial Conference on The New Frontiers of Entrepreneurship, 21-23 March, Gandhinagar, India.

Nieman, G, Hough, J \& Nieuwenhuizen, C. 2003. Entrepreneurship: A South African perspective. (1st ed). Pretoria: Van Schaik Publishers.

Parker, SC. 2011. Intrapreneurship or entrepreneurship. Journal of Business Venturing, 26: 19-34.

Sáez-Martinez, FJ \& Gonzalez-Moreno, A. 2001. Strategic renewal, cooperation, and performance: A contingency approach. Journal of Management and Strategy, 2(4): 43-55.

Sayeed, OB \& Gazdar, MK. 2003. Intrapreneurship: Assessing and defining attributes of intrapreneurs. Journal of Entrepreneurship, 12: 75-88. 
Sharma, P \& Chrisman, JJ. 1999. Toward a reconciliation of the definitional issues in the field of corporate entrepreneurship. Entrepreneurship Theory and Practice, 23(3): 11-27.

Shaughnessy, JJ, Zechmeister, EB \& Zechmeister, JS. 2009. Research methods in psychology. (8th ed). New York: McGraw-Hill.

Subramanian, N. 2005. The economics of intrapreneurial innovation. Journal of Economic Behavior \& Organization, 58: 487-510.

Teltumbde, A. 2006. Entrepreneurs and intrapreneurs in corporations. Vikalpa: The Journal for Decision Makers, 31(1): 129-132.

Teng, B-S. 2007. Corporate entrepreneurship activities through strategic alliances: A resource-based approach toward competitive advantage. Journal of Management Studies, 44(1): 119-142.

Thornhill, S. \& Amit, R. 2000. A dynamic perspective of internal fit in corporate venturing. Journal of Business Venturing, 16: 26-50.

Urbano, D \& Turro, A. 2013. Conditioning factors for corporate entrepreneurship: an in(ex)ternal approach. International Entrepreneurship Management Journal, 9(2013): 379-396.

Van Wyk, R \& Andonisi, M. 2012. Ascendants of corporate entrepreneurship. South African Journal of Business Management, 43(3): 65-78.

Villiers-Scheepers, MJ. 2011. Motivating intrapreneurs: The relevance of rewards. Industry and Higher Education, 25(4): 249-263.

Wolcott, RC \& Lippitz, MJ. 2007. The Four Models of corporate entrepreneurship. MITSloan Management Review. Retrieved from: http://sloanreview.mit.edu/article/the-four-models-of-corporateentrepreneurship/ Accessed: 04-02-2014.

Yiu, DW, Lau, C \& Burton, GD. 2007. International venturing by emerging economy firms: the effects of firm capabilities, home country networks, and corporate entrepreneurship. Journal of International Business Studies, 38: 519-540.

Zahra, SA. 1991. Predictors and financial outcomes of corporate entrepreneurship: an exploratory study. Journal of Business Venturing, 6: 259-285. 
Zahra, SA. 1995. Corporate entrepreneurship and financial performance: The case of management leveraged buyouts. Journal of Business Venturing, 10(3): 225-247.

Zahra, SA. 1996. Governance, ownership, and corporate entrepreneurship: the moderating impact of industry technology opportunities. Academy of Management Journal, 39(6): 1713-1735.

Zahra, SA. 2005. Corporate Entrepreneurship and Growth. Cheltenham: Edward Elgar Publishing Limited.

Zahra, SA. \& Covin, JG 1995. Contextual influences in the corporate entrepreneurship-performance relationship: A longitudinal analysis. Journal of Business Venturing, 10(1): 43-58.

Zahra, SA \& Garvis, DM. 2000 International corporate entrepreneurship and firm performance: The moderating effect of international environmental hostility. Journal of Business Venturing, 15(5-6): 469-492.

Zahra, SA, Neck, HM \& Kelly, DM. 2004. International corporate entrepreneurship and the evolution of organizational competence: $A$ knowledge-based perspective. Advances in Entrepreneurship, Firm Emergence and Growth, 7: 145-171. 